\title{
Eko teknologi untuk pencegahan kebakaran pada lahan gambut di Desa Rimbo Panjang, Kecamatan Tambang, Kampar
}

\author{
Saktioto*, Ari Sulistyo Rini, Rahma Dewi, \& Deprianto \\ Universitas Riau \\ * saktioto@yahoo.com
}

\begin{abstract}
Abstrak. Kebakaran lahan gambut dapat menimbulkan emist GRK Identifikasi yang ada di di Desa Rimbo Panjang, Kecamatan Tambang, Kampar, dimana adanya keluhan masyarakat tentang kondisi lingkungan atau kabut asap. Tujuan kegiatan ini adalah untuk menerapkan eko teknologi pencegahan kebakaran di lahan gambut di Desa Rimbo Panjang, Kecamatan Tambang Kabupaten Kampar Provinsi Riau. Adapun metode yang diterapkan adalah Eko Teknologi dengan sistim solidifikasi artinya memperkecil pori-pori tanah gambut sehingga dapat memadamkan api dengan cepat. Metode lainnya yang digunakan adalah dengan menghambat kontak api dengan udara luar (oksigen) yaitu dengan cara penyiraman menggunakan campuran deterjen. Hasil yang diperoleh dari kegiatan ini menunjukkan bahwa berdasarkan water table pada lahan gambut ditemukan bervariasi dan termasuk kategori gambut dalam, hanya sebagian kecil di dusun 1 yang ditemukan water table pada kedalaman $20 \mathrm{~cm}$. Berdasarkan kondisi lapisan lempung ternyata juga bervariasi ditemukan pada kedalaman antara 2,5 m sampai 6 meter. Berdasarkan hasil observasi di lapangan, maka kondisi gambut di Rimbo Panjang ini rentan dengan kebakaran. Simulasi kebakaran yang telah dilakukan dengan cara membuat kondisi gambut buatan yang kemudian dilakukan pembakaran menunjukkan bahwa metode Eko Teknologi telah mampu melakukan pemadaman kebakaran pada lahan gambut dengan cepat.
\end{abstract}

Kata kunci: eko; teknologi; gambut; kebakaran; solidifikasi

\begin{abstract}
Peatland fires can cause emist GHG identification in Rimbo Panjang village, Tambang sub-district, Kampar whre there are community complaints about environmental conditions or smog. The purpose of this activity is to implement the technology of fire prevention on peat land in Rimbo Panjang Village, Tambang District, Kampar Regency, Riau Province. The method applied is Eco Technology with a solidification system which means reducing the pores of peat so that it can extinguish the fire quickly. The other method used is by blocking fire contact with outside air (oxygen) that is by watering using a mixture of detergent. The results obtained from this activity showed that based on the water table on peatland it was found to be varied and included in the category of deep peat, only a small portion in village 1 found a water table at a depth of $20 \mathrm{~cm}$. Based on the condition of the clay layer it also turns out to be found in depths between $2.5 \mathrm{~m}$ to 6 meters. Based on the results of observations in the field, the condition of peat in Rimbo Panjang is vulnerable to fire. Fire simulations that have been carried out by making artificial peat conditions which are then combusted show that the Eko Technology method has been able to fire out peatlands quickly.
\end{abstract}

Keywords: eco; technology; peat; fire; solidification

To cite this article: Saktioto, A. S. Rini, R. Dewi, \& Deprianto. 2019. Eko teknologi untuk pencegahan kebakaran pada lahan gambut di Desa Rimbo Panjang, Kecamatan Tambang, Kampar. Unri Conference Series: Community Engagement 1: 434-441 https://doi.org/10.31258/unricsce.1.434-441

(C) 2019 Authors

Peer-review under responsibility of the organizing committee of Seminar Nasional Pemberdayaan Masyarakat 2019 


\section{PENDAHULUAN}

Lahan gambut merupakan ekosistem penyimpan dan penyerap karbon yang penting, diperkirakan menyimpan lebih dari $600 \mathrm{Gt}$ karbon. Ketika kering, lahan gambut mudah terbakar. Emisi karbon dari lahan gambut sangat berfluktuasi tergantung banyak faktor diantaranya iklim, tanah, dan hidrologi (Saiz, 2007). Tanah gambut adalah jenis tanah yang terbentuk dari proses dekomposisi vegetasi pepohonan yang tidak sempurna karena kondisi tanahnya digenangi air. Material organik dari proses dekomposisi tersebut terus menumpuk dalam waktu lama sehingga membentuk lapisan-lapisan. Biasanya lapisan tersebut lebih dari $50 \mathrm{~cm}$. Tanah jenis ini dapat dijumpai di daerah-daerah jenuh air seperti rawa, cekungan, dan pantai. Faktor-faktor lingkungan yang sangat berpengaruh terhadap besarnya emisi karbon dari lahan gambut adalah suhu dan kelembaban tanah, serta daya hantar listrik (Setia, 2011). Keunikan dari tanah gambut adalah memiliki kemampuan menyimpan air yang baik. Bahkan dapat menyimpan air hingga 13 kali dari bobotnya. Kerusakan pada lahan gambut seringkali terjadi akibat aktivitas manusia, misalnya menjadikan hutan gambut sebagai lahan pertanian, perkebunan, kehutanan bahkan industri (Firmansyah, 2012). Lahan gambut di negara-negara Asia Tenggara, seperti Indonesia, mengalami laju kerusakan paling tinggi karena konversi lahan untuk perkebunan kelapa sawit dan pulp terus meningkat. Proses pengubahan lahan gambut biasa diawali dengan proses pembabatan hutan (Suwarno et al., 2018) dan selanjutnya adalah pengeringan lahan yang bertujuan untuk mengeluarkan air yang terkandung dalamnya. Pengeringan dapat dilakukan dengan cara membuat parit atau saluran drainase agar air mengalir keluar. Sekali air dikeluarkan dari lahan gambut, maka lahan gambut akan kehilangan kemampuannya untuk menyimpan air. Hal ini karena lahan gambut bersifat irreversible atau tidak dapat dikembalikan. Dampaknya bermacam-macam, di musim kemarau akan rawan kebakaran, di musim hujan akan rawan banjir. Bahaya dari rusaknya lahan gambut tidak hanya berdampak secara lokal dan regional saja, melainkan juga berkontibusi pada bencana global seperti perubahan iklim seperti yang terjadi di Desa Rimbo Panjang.

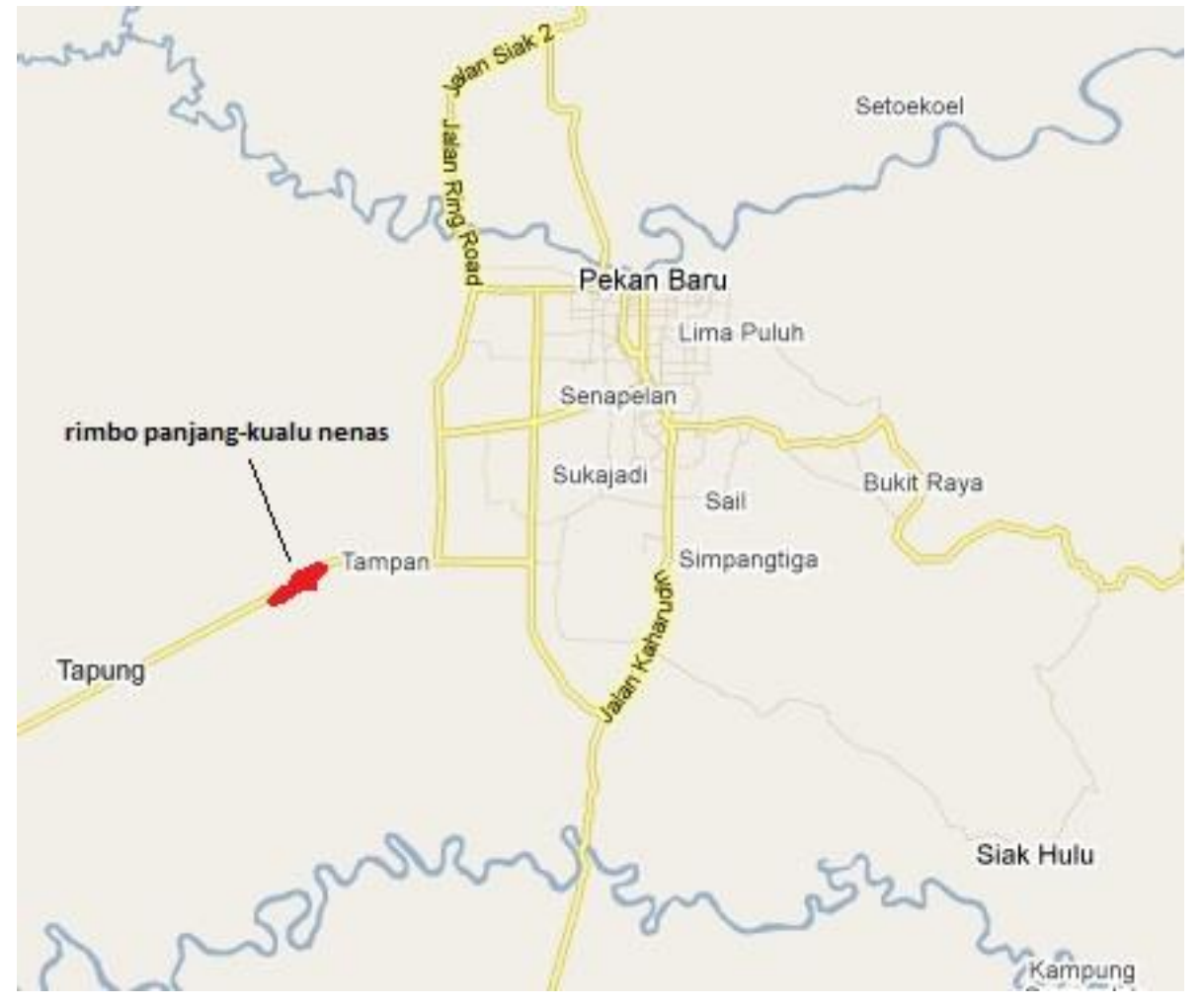

Gambar 1. Peta Rimbo Panjang

Kebakaran pada lahan gambut di Desa Rimbo Panjang, Kabupaten Kampar secara geografis memiliki kondisi dataran rendah dan didominasi dengan areal gambut. Areal gambut yang kering akan mudah terbuka terbakar, dan jika terjadi kebakaran di lahan gambut maka sangat sulit padamnya.

Identifikasi yang ada di Desa Rimbo Panjang, Kecamatan Tambang, Kampar bahwa ada peristiwa kebakaran lahan yang hampir mengenai pemukiman penduduk pada tahun 2015. Bahwa adanya keluhan 
masyarakat di Desa Rimbo Panjang, Kecamatan Tambang, Kampar tentang kondisi lingkungan atau kabut asap.

Penanganan atau tindakan yang bersifat spesifik dalam memanfaatkan lahan gambut untuk kegiatan usaha tani perlu dilakukan (Gambar 3). Tindakan ini perlu dilakukan karena lahan gambut mempunyai karakteristik yang berbeda dibanding lahan mineral, lahan gambut khususnya gambut tropika mempunyai karakteristik yang sangat beragam, baik secara spasial maupun vertikal (Sitorus, 2002). Berdasarkan analisis situasi di atas maka perlu dilakukan penyuluhan Eko Teknologi pengelolaan lahan gambut untuk pencegahan kebakaran di lahan gambut. Penyuluhan ini akan menciptakan lingkungan yang berkualitas sehingga dapat meningkatkan pemahaman masyarakat tentang antisipasi pencegahan kebakaran lahan.

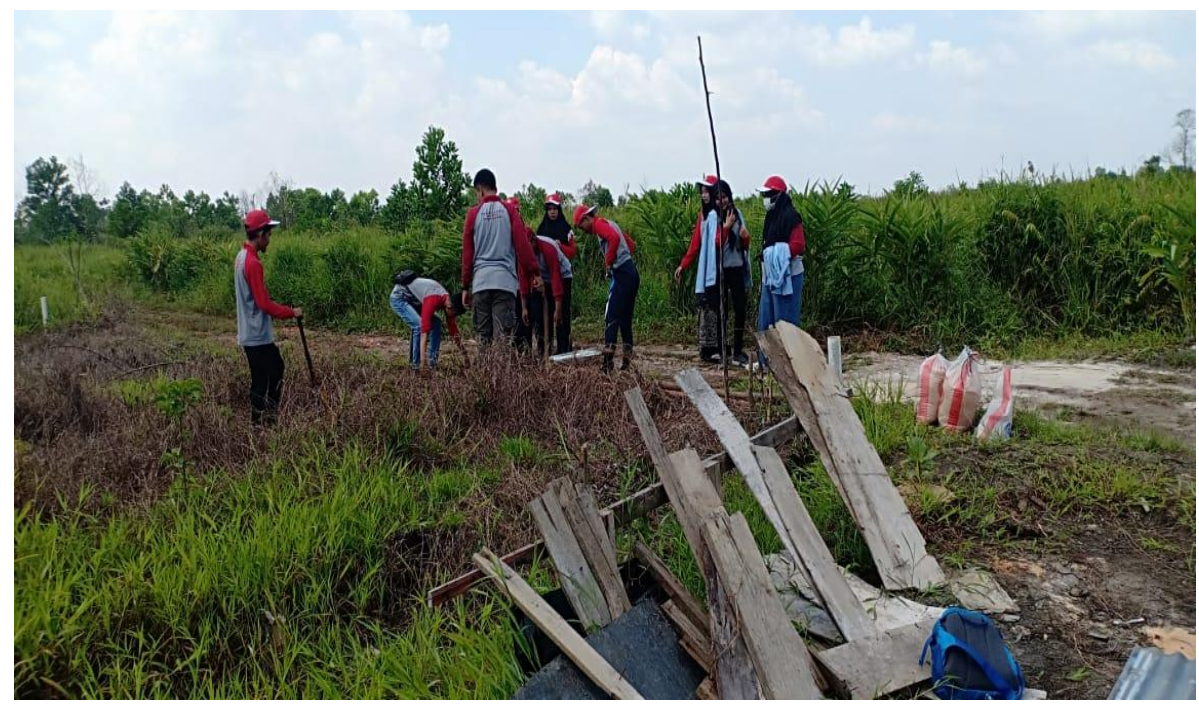

Gambar 2. Observasi Karakteristik Gambut oleh Mahasiswa Kukerta terintegrasi

Gambar 2 menunjukkan kegiatan observasi yang dilakukan Tim Kukerta terintegrasi di lahan gambut Desa Rimbo Panjang. Karakteristik gambut sangat ditentukan oleh ketebalan gambut, substratum (lapisan tanah mineral di bawah gambut), kematangan, dan tingkat pengayaan. Lahan gambut tropika umumnya tergolong sesuai marginal untuk pengembangan pertanian, dengan faktor pembatas utama kondisi media tanam yang tidak kondusif untuk perkembangan akar, terutama kondisi lahan yang jenuh air, bereaksi masam,dan mengandung asam-asam organik pada level yang bisa meracuni tanaman,sehingga diperlukan beberapa tindakan reklamasi agar kondisi lahan gambut menjadi lebih sesuai untuk perkembangan tanaman.

Berdasarkan identifikasi diatas maka permasalahan yang ada di Desa Rimbo Panjang, Kecamatan Tambang, Kampar, yaitu:

a. Adanya peristiwa kebakaran lahan gambut yang hampir mengenai pemukiman penduduk

b. Adanya keluhan masyarakat tentang kondisi lingkungan atau kabut asap.

c. Masyarakat petani belum mengenal Eko-Teknologi untuk penanggulangan kebakaran hutan.

\section{METODE}

Metode yang dilakukan dalam penyuluhan ini adalah metode ceramah dan praktek yaitu dengan mendesain sistem eko teknologi yang dilakukan di Desa Rimbo Panjang, Kecamatan Tambang, Kampar, Khususnya Yang Berkaitan Dengan Permasalahan untuk meningkatkan kualitas lingkungan hidup dalam hal penanggulangan kebakaran lahan gambut di Desa Rimbo Panjang, Kecamatan Tambang, Kampar. Penyuluhan diarahkan melalui sosialisasi eko teknologi, penggunaan Eko-Teknologi untuk pengelolaaan lingkungan dengan demikian kebakaran lahan gambut dapat dicegah.

\section{PEMBAHASAN}

Pelaksanaan pengabdian ini di bagi atas dua tahapan yaitu:

\section{(a) Tahapan di Kelas}

Tahapan Penyampaian Materi Penyuluhan Tentang eko Teknologi pencegahan kebakaran lahan gambut dilakukan di ruang kelas/aula Desa Rimbo Panjang ini diawali dengan memberikan materi penyuluhan tentang 
eko teknologi pencegahan kebakaran lahan gambut. Masyarakat dengan antusias memperhatikan materi penyuluhan yang disampaikan oleh Tim, serta prakteknya dibantu oleh mahasiswa Kukerta dalam kegiatan Kukerta terintegrasi.

Penerapan Eko-Teknologi bisa mencegah terjadinya kebakaran pada lahan gambut di Desa Rimbo Panjang, Kabupaten Kampar Provinsi Riau. Eko-Teknologi merupakan suatu teknologi pengelolaan sumberdaya air di lahan gambut untuk mengontrol jumlah dan tinggi muka air sehingga mampu menjaga kelembaban gambut untuk pertumbuhan tanaman yang optimal, meminimalkan subsidensi dan mencegah kebakaran (Nurhidayah, et al, 2014).

Eko-Teknologi merupakan hasil dari penelitian, pembelajaran, praktek, dan perbaikan berkesinambungan yang dilakukan dalam pengelolaan hutan tanaman lestari di lahan gambut. Teknologi ini mampu menanggulangi kebakaran pada lahan gambut sehingga terjadi pengelolaan air dengan indicator water table yang dangkal. Hal ini juga dapat diatasi dengan pengaturan muka air tanah dilakukan melalui "hydro buffer" di antara tanaman pokok dan kawasan lindung. Dengan begitu, ketinggian air dapat diatur mendekati permukaan pada kawasan gambut, kemudian diturunkan secara bertahap di areal hydro buffer agar sesuai untuk kebutuhan tanaman pokok (Purbowoseso, 2000).

Perubahan ketinggian muka air diantara selang kontur (gradient) dapat dibangun bendungan untuk mengatur dan menjaga ketinggian muka air tanah. Bendungan dengan saluran pelimpah, dengan dam sisir berfungsi seperti pintu air otomatis yang akan melimpahkan air yang berlebihan pada musim penghujan dan mempertahankan air pada saat musim kemarau.

Pengelolaan air di lahan gambut berdasarkan pada sistem zonasi lahan terpadu yang bertujuan untuk menjaga kelembaban gambut dengan tujuan (Budi, 2012):

1. Pertumbuhan tanaman optimal;

2. Gambut tidak mudah terbakar;

3. Subsidensi gambut terkendali;

4. Emisi karbon dapat ditoleransi.

5. Menjaga muka air tanah (water table) pada kisaran yang tepat di Kawasan Lindung, Penyangga, Tanaman Pokok dan Tanaman Kehidupan.

6. Penggunaan dam dan parit sisir untuk mengatur tinggi air (water level) dan laju drainase di saluran.

Sementara Kepentingan pengelolaan air di lahan gambut berguna untuk:

1. Meningkatkan aksesibilitas.

2. Memperlancar transportasi.

3. Menanggulangi kebakaran hutan.

4. Menjaga keanekaragaman hayati.

5. Meningkatkan produktivitas lahan.

6. Menurunkan emisi karbon.

Kompetensi Water Managemen bertujuan untuk:

1. Mengetahui faktor-faktor berpengaruh terhadap terhadap pertumbuhan tanaman.

2. Mengetahui kelembaban tanah yang ideal bagi pertumbuhan tanaman.

3. Mampu mengkondisikan kelembaban tanah yang ideal bagi pertumbuhan tanaman.

4. Mampu mengatasi permasalahan air (kebanjiran + kekeringan) yang berakibat buruk bagi pertumbuhan tanaman.

5. Mampu mengelola tata air secara keseluruhan.

\section{(b) Tahapan di Lapangan}

Tahapan ini untuk praktek langsung pencegahan kebakaran di lahan gambut yang ada di Desa Rimbo Panjang Kecamatan Tambang Kabupaten Kampar Provinsi Riau (Gambar 3). Pencegahan Kebakaran pada lahan gambut dapat dilihat dari karakteristik apakah Gambut tersebut tidak mudah terbakar. Tim Kukerta bersama mahasiswa Kukerta telah melakukan sosialisasi kepada masyarakat di Desa Rimbo Panjang tentang teknik melakukan klasifikasi gambut apakah mudah terbakar atau tidak (Gambar 4). 


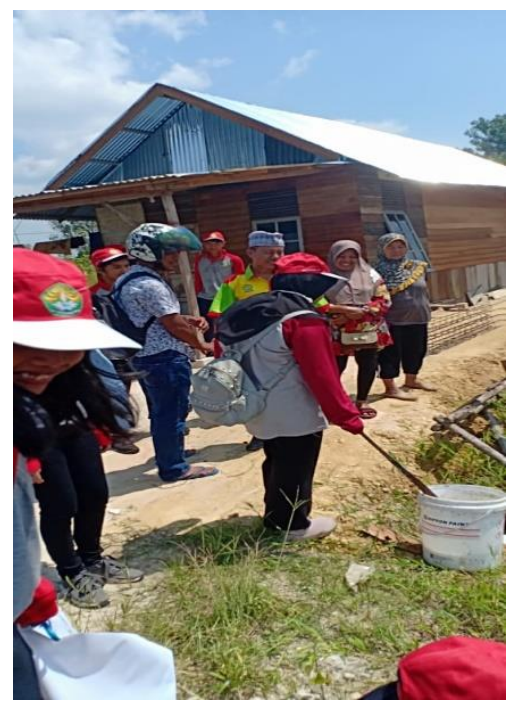

Gambar 3. Mahasiswa sedang melakukan praktek lapangan eko-teknologi

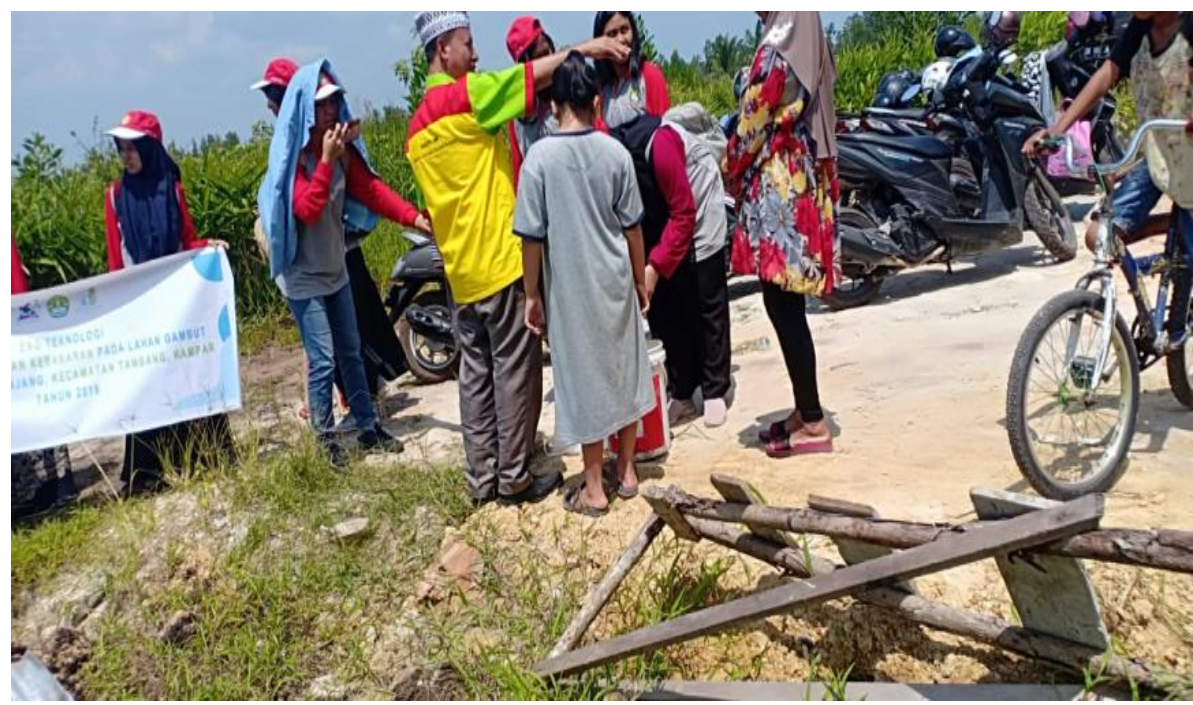

Gambar 4. Praktek pengenalan Karakteristik lahan gambut

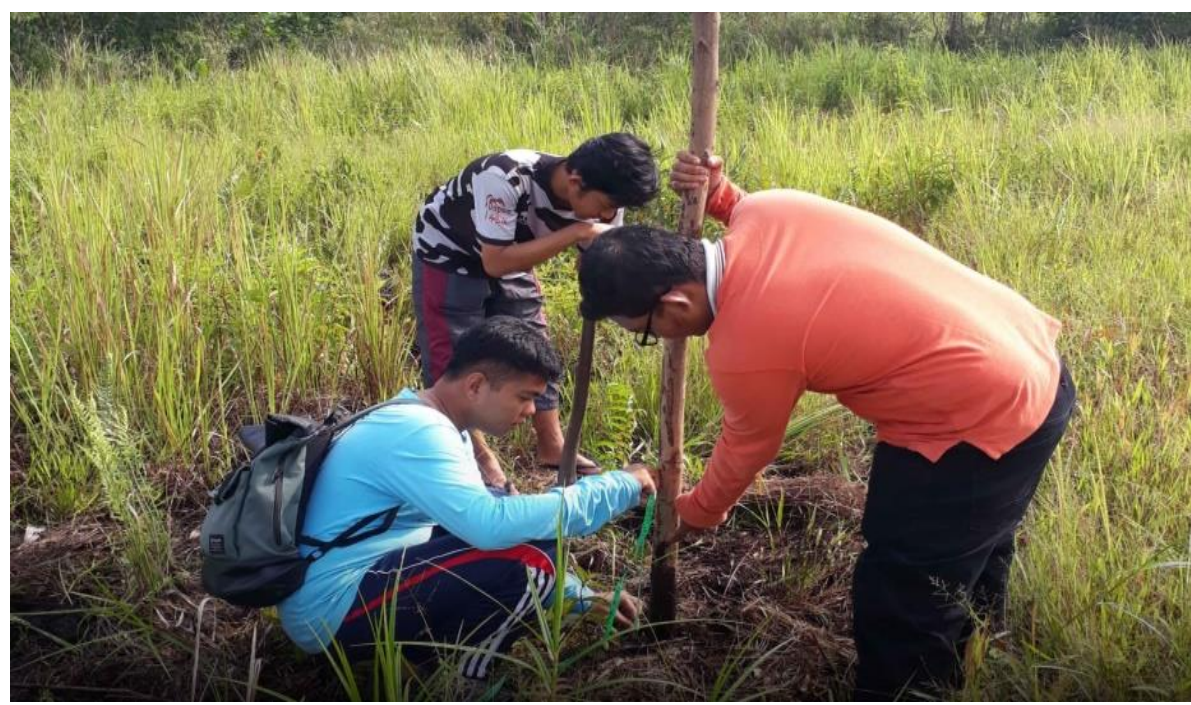

Gambar 5. Praktek penentuan water table dan kedalaman gambut 
Penanggulangan kebakaran pada lahan gambut dapat juga dilakukan dengan cara menjaga muka air tanah (water table) pada kisaran yang tepat yaitu kecil dari $20 \mathrm{~cm}$. Tim mahasiswa Kukerta terintegrasi sedang melakukan praktek untuk melihat water table di lahan gambut yang ada di Desa Rimbo Panjang (Gambar 5).

Penerapan Eko Teknologi untuk mencegah kebakaran lahan gambut telah dilakukan secara simulasi, yaitu membuat kebakaran gambut secara buatan. Praktek ini bertujuan untuk melihat sejauh mana efesiensi Eko Teknologi dapat memadamkan kebakaran. Berdasarkan hasil simulasi didapatkan bahwa Eko Teknologi dapat memadamkan api dengan cepat dalam hitungan menit (Gambar 6).

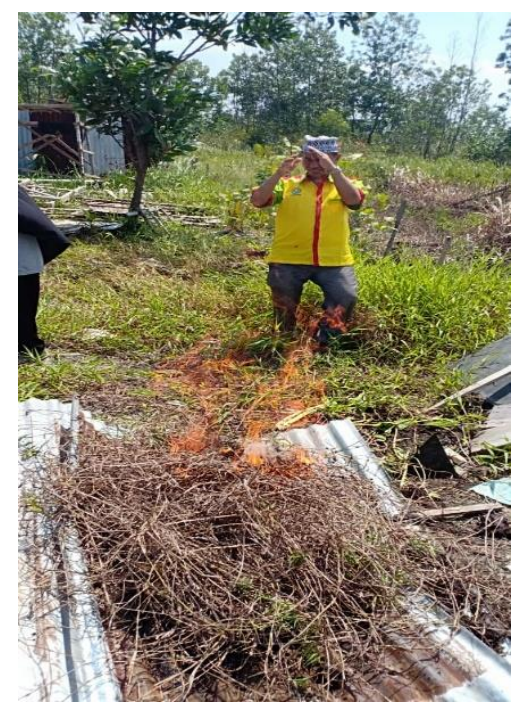

Gambar 6. Simulasi kebakaran pada lahan gambut

Mahasiswa Kukerta terintegrasi bersama dosen pembimbing melakukan foto bersama seusai kegiatan praktek lapangan (Gambar 7) terlihat bahwa mahasiswa dengan antusias melakukan kegiatan pengabdian ini dan telah mampu menyerap transfer eko teknologi yang diajarkan dosen pembimbing kukerta.

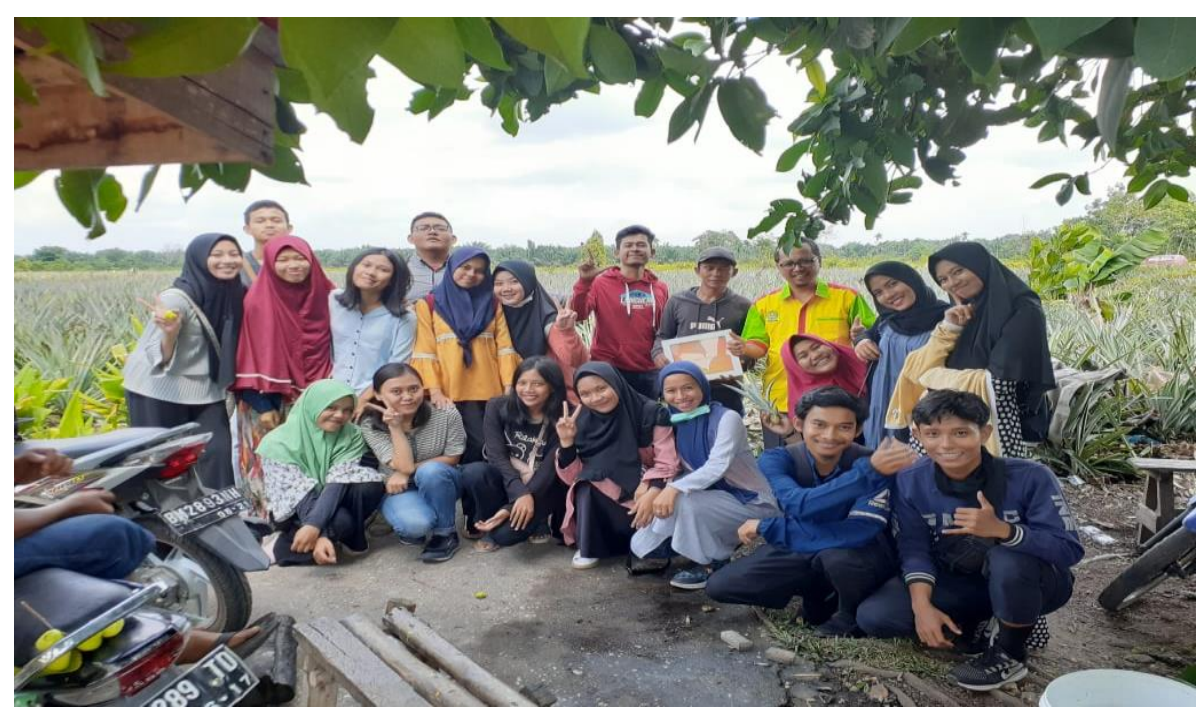

Gambar 7. Foto bersama mahasiswa kukerta seusai praktek lapangan

Hasil eko teknologi pada lahan gambut di desa Rimbo panjang dapat dikatakan bahwa water table pada lahan gambut ditemukan bervariasi dan termasuk kategori gambut dalam, hanya sebagian kecil di dusun 1 yang ditemukan water table pada kedalaman $20 \mathrm{~cm}$. Berdasarkan kondisi lapisan lempung ternyata juga bervariasi ditemukan pada kedalaman antara 2,5 m sampai 6 meter. Berdasarkan hasil observasi di lapangan, maka kondisi gambut di Rimbo Panjang ini rentan dengan kebakaran. Simulasi kebakaran yang telah dilakukan dengan cara membuat kondisi gambut buatan yang kemudian dilakukan pembakaran menunjukkan bahwa metode eko teknologi telah mampu melakukan pemadaman kebakaran pada lahan gambut dengan cepat. 
Mahasiswa Kukerta terintegrasi bersama dosen pembimbing dan aparat pimpinan desa Rimbo Panjang, Kecamatan Tambang, Kabupaten Kampar, berfoto bersama seusai pelaksanaan Lokakarya tentang Eko Teknologi untuk pencegahan kebakaran pada lahan gambut (Gambar 8).

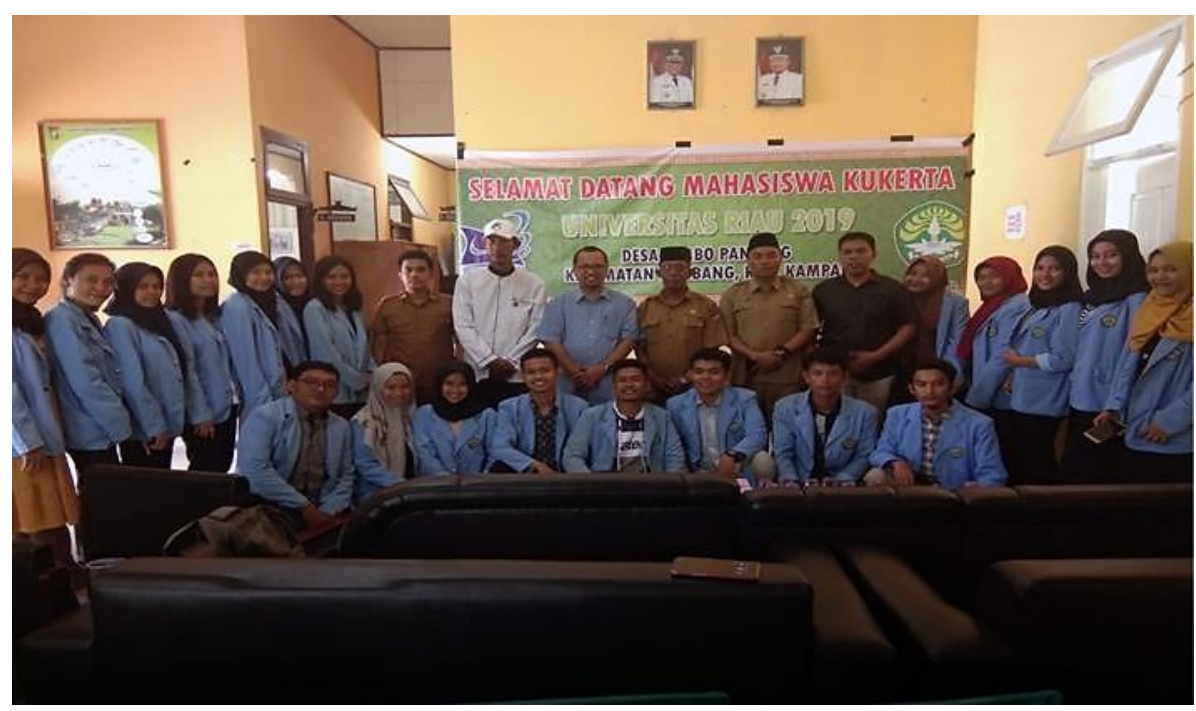

Gambar 8. Berfoto bersama selesai kegiatan

\section{KESIMPULAN}

Melalui pengabdian yang telah dilakukan ini ternyata memberikan dampak positif bagi masyarakat di Desa Rimbo Panjang untuk berusaha menjaga lingkungan agar tidak terjadi kebakaran lahan gambut.

Water table pada lahan gambut ditemukan bervariasi dan termasuk kategori gambut dalam. Hal ini menyebabkan sering terjadi kebakaran lahan gambut di Desa Rimbo Panjang. Sebagian kecil di dusun 1 yang ditemukan water table pada kedalaman $20 \mathrm{~cm}$.

Lempung ternyata juga bervariasi ditemukan pada kedalaman antara 2,5 m sampai 6 meter. Berdasarkan hasil observasi di lapangan, maka kondisi gambut di Rimbo Panjang ini rentan dengan kebakaran.

Simulasi kebakaran yang telah dilakukan dengan cara membuat kondisi gambut buatan yang kemudian dilakukan pembakaran menunjukkan bahwa metode eko teknologi telah mampu melakukan pemadaman kebakaran pada lahan gambut dengan cepat.

Berdasarkan hasil pelaksanaan pengabdian pada masyarakat yang telah dilakukan serta analisa, maka dapat diambil kesimpulan yaitu telah berhasil diterapkan eko teknologi pencegahan kebakaran pada lahan gambut di Desa Rimbo Panjang Buluh Kecamatan Tambang Kabupaten Kampar Provinsi Riau.

\section{UCAPAN TERIMA KASIH}

Ucapan terima kasih kepada Lembaga Penelitian dan Pengabdian kepada Masyarakat Universitas Riau yang telah memberi bantuan dana, dan kepada mahasiswa Kukerta yang telah membantu dalam praktek lapangan bersama masyarakat.

\section{DAFTAR PUSTAKA}

Budi I. S. 2012. Training On: Water Management For Forest Plantation In Tropical Peatlands.

Firmansyah, M. A., \& M. S. Mokhtar. 2012. Profil ICCTF di Kalimantan Tengah: pengelolaan lahan gambut berkelanjutan. BPTP Kalimantan Tengah.

Nurhidayah, L., Z. Lipman, \& S. Alam. 2014. Regional environmental governance: an evaluation of the ASEAN legal framework for addressing transboundary haze pollution. Australian Journal of Asian Law 15(1).

Purbowoseso, B. 2000. Buku Ajar Pengendalian Kebakaran Hutan Fakultas Kehutanan Universitas Lambung Mangkurat. Banjarbaru.

Saiz, G., et al. 2007. Assesment off soil $\mathrm{CO}_{2}$ efflux and its components using a process based model in a young temperate forest site. Geoderma 139(1-2): 79-89. 
Setia, R., P. Marschner, J. Boldock, D. Chittleborough, \& V. Verma. 2011. Relationship between carbon dioxide emission and soil properties in salt-affected landscapes. Soil biology and biochemistry 43(3): 667-674

Sitorus, B. P. 2002. Pemanfaatan TMC-BPPT Untuk Antisipasi Bencana Iklim dan Cuaca Di Indonesia. Makalah disampaikan dalam Panel dan Seminar PIT HAGI ke-27 tanggal 21-23 Oktober 2002 di Malang Jawa Timur.

Suwarno, E., Hadinoto, \& M. Ikhwan. 2018. Prioritas konservasi lahan dan arahan programnya di Kelurahan Minas Jaya Provinsi Riau. Riau Journal of Empowerment 1(1): 11-21. https://doi.org/10.31258/raje.1.1.2 